\title{
The effect of inflammatory response modulator agents on gingivitis and periodontitis
}

\author{
Efeito do uso de agentes moduladores de resposta inflamatória em gengivites e periodontites
}

\author{
Juliano CAVAGNI ${ }^{1}$ \\ Francisco Wilker Mustafa Gomes MUNIZ \\ Cassiano Kuchenbecker RÖSING ${ }^{1}$
}

\begin{abstract}
Periodontal diseases are infecto-inflammatory diseases. Literature, has tried to elucidate the infections component of gingivitis and periodontitis, for several years. In recent years, much has been discussed about the role of the host response modulators to periodontal therapeutic procedures. The aim of the present literature review was to evaluate the effect of host response modulating agents (anti-inflammatories) on the pathogenesis of gingivitis and periodontitis. A search in the main databases was performed and human and animal studies were selected. The majority of studies was performed in humans and non-steroidal anti-inflammatory drugs in different dosages were used. The results have shown a potential benefit of the non-steroidal anti-inflammatory drugs concerning the microbial challenge. However, this benefit seems not to occur in the long term, thus not supporting it as a periodontal therapeutic approach. Few studies evaluated the effect of steroidal antiinflammatory drugs on the pathogenesis of periodontal diseases. Moreover, the results in humans and animals are controversial, pointing to a possible deleterious effect of steroidal anti-inflammatory drugs on periodontal structures.
\end{abstract}

Indexing terms: Anti-inflammatory agents. Gingivitis. Periodontal diseases. Periodontitis.

\section{RESUMO}

Doenças periodontais são doenças de natureza infecto-inflamatória. A literatura, por muitos anos, preocupou-se em elucidar somente o aspecto infeccioso de gengivites e periodontites. Nos últimos anos, muito tem-se debatido quanto ao papel da modulação da resposta do organismo como medida terapêutica periodontal. Nesse sentido, o objetivo da presente revisão de literatura foi avaliar o efeito de agentes moduladores da resposta inflamatória (antiinflamatórios) na patogênese de gengivites e periodontites. Foi realizada uma busca nas principais bases de dados sendo selecionados estudos em humanos e em modelo animal. Observou-se que a maioria dos estudos foi realizada em humanos e utilizou antiinflamatórios não-esteróides) em diferentes posologias. Os resultados dos estudos apontam para um potencial efeito benéfico dos antiinflamatórios não-esteróides frente ao desafio microbiano. Entretanto, esse benefício parece não ocorrer a longo prazo não sendo justificado seu uso como medida terapêutica periodontal. Poucos estudos avaliaram o efeito dos antiinflamatórios esteróides na patogênese das doenças periodontais. Além disso, os resultados dos estudos tanto em humanos quanto em animais são controversos, mas apontam para um possível efeito deletério dos antiinflamatórios esteróides sobre as estruturas periodontais.

Termos de indexação: Anti-inflamatórios. Gengivite. Doenças periodontais. Periodontite.

\section{INTRODUCTION}

The Periodontal science has undergone many changes related to the way of acting and thinking, in the last decades. For instance, the surgical-restorative paradigm, which ignored the prevention concept, and the treatment modalities based exclusively on the professional experiences have been changed to a model based on health promotion and the conscious usage of the best scientific evidence available ${ }^{1}$. Therefore, in agreement with this evolutionary process, many models were proposed in order to explain the health-disease process in the periodontal tissues, and currently the most acceptable one has been proposed by Page \& Kornman².

This model states that the microbiological challenge, including lipopolysaccharide liberations, cause injuries in the periodontal tissues, leading, an antigenantibody inflammatory response. This reaction increases the production of proinflammatory cytokines, prostangladins and matrix metalloproteinases, such as collagenase,

\footnotetext{
${ }^{1}$ Universidade Federal do Rio Grande do Sul, Faculdade de Odontologia. Rua Ramiro Barcellos, 2492, Bom Fim, 90035-003, Porto Alegre, RS, Brasil. Correspondência para / Correspondence to: CK RÖSING. E-mail: <ckrosing@hotmail.com>.
} 
which is responsible for the connective tissue metabolism and osteoclast activation that is responsible for the bone tissue metabolism. This process produces clinical signals of periodontal inflammation, inducing alveolar bone loss and consequently clinical attachment loss.

For several years, the treatment strategies for the periodontal diseases were based solely in the complete removal of the dental biofilm and its components of the dental-gingival area and of the sulcus/periodontal pockets. However, the concern with factors related to the inflammatory response has been increasing mainly due to new techniques related to Molecular Biology and Microscopy ${ }^{3}$. A gram-negative bacterial infection is necessary, although not sufficient, to promote a periodontal pocket formation.

Therefore, the host response mediates the periodontal destruction when these microorganisms are present ${ }^{2}$. It is crucial, in this context, the importance of studying the effects of the host response modulator agent including steroidal (SAIDs) and nonsteroidal antiinflammatory drugs (NSAIDs), since their potential in the management of the periodontal disease etiopathogenesis has been demonstrated.

Different studies have shown the role of these medications in the disease development, more specifically with a view to understanding the pathogenesis and, in the future, as prevention and/or treatment modality. The NSAIDs have been extensively studied in Periodontology ${ }^{4-10}$. On the other hand, evidences on steroidal anti-inflammatory drugs are scarce ${ }^{11-12}$. Therefore, the objective of this study was to review the literature about the effect of these drugs in the gingivitis and periodontitis pathogenesis. The analyzed studies were grouped in tables, subdivided by drug type (steroidal/nonsteroidal) and study model (animal/human) in order to promote better understanding.

\section{Nonsteroidal anti-inflammatory drugs and periodontal disease}

\section{Animal evidences}

Since the end of the 1970, several studies, using animal models, have assessed the role of NSAIDs in the periodontal tissues injured by the dental biofilm (Table 1). Although it is difficult to extrapolate the results of animal studies to humans, it is equally unwise to ignore the many similarities that scientists have demonstrated in these models ${ }^{13}$. Many animal models using NSAIDs of experimental periodontal disease have been proposed throughout the years, such as ligature induced periodontitis ${ }^{4,14}$ and periodontitis induced by diet consistence modification ${ }^{5-7,15}$. These are the most effective methods to accumulate plaque and induce periodontal disease (Table 1). Several NSAIDs were evaluated, such as indomethacin, flurbiprofen, and naproxen. Additionally, comparisons between those drugs and between different administrations (locally delivered and systemically) were performed.

Nyman et al. ${ }^{4}$ have evaluated the use of indomethacin $(1 \mathrm{mg} / \mathrm{kg})$ in reducing the inflammatory response followed by bone resorption in Beagle dogs for a period of 28 days. The results demonstrated a reduction in the initial inflammatory response, delaying the alveolar bone resorption. Additionally, when the subgingival plaque was higher, the indomethacin showed the worst effect in comparison to the animals with well-controlled plaque in the gingival margin. It is suggested that, similarly to the humans, the supragingival biofilm influence the subgingival area.

During 2 weeks Weaks-Dybvig et al. ${ }^{14}$ evaluated, a higher dose of indomethacin $(5 \mathrm{mg} / \mathrm{kg}$ ) in monkeys and compared to a control group (placebo). Similarly to the study of Nyman et al. the use of indomethacin almost annulled the loss of bone mass, decreasing considerably the density of osteoclast in the experimental period.

The use of Flurbiprofen $(0.02 \mathrm{mg} / \mathrm{kg})$, associated with surgical periodontal therapy, was evaluated by Williams et al. ${ }^{5}$. In the groups treated with Flubiprofen, the rate of radiographic bone loss was lower, $91 \%$ and $66 \%$, respectively, either with or without adjuvant periodontal therapy. Therefore, the groups treated with Flubiprofen, either with or without surgical procedures, showed a smaller rate of alveolar bone loss when compared to a placebo group with or without surgical periodontal therapy.

Likewise, Howell et al. ${ }^{7}$ evaluated the effect of Naproxen in the rate of alveolar bone loss in Beagle dogs in comparison to a placebo group. It was shown that the placebo group presented progression of alveolar bone loss, while, in the Naproxen group, the rate of bone loss was significantly smaller up to 4 months of the study. However, after 7 months, the difference related to the pre-treatment period was not statistically significant. The rate comparisons between both groups, in relation to the pre- to post-treatment period, was $38 \%$ of alveolar bone loss in the placebo group and $61 \%$ of alveolar bone gain in the Naproxen group. This result indicates a positive effect of this drug in the periodontal tissues on Beagle dogs. 
Table 1. The action of NSAIDs in the periodontal tissues in animal studies. Porto Alegre, 2011.

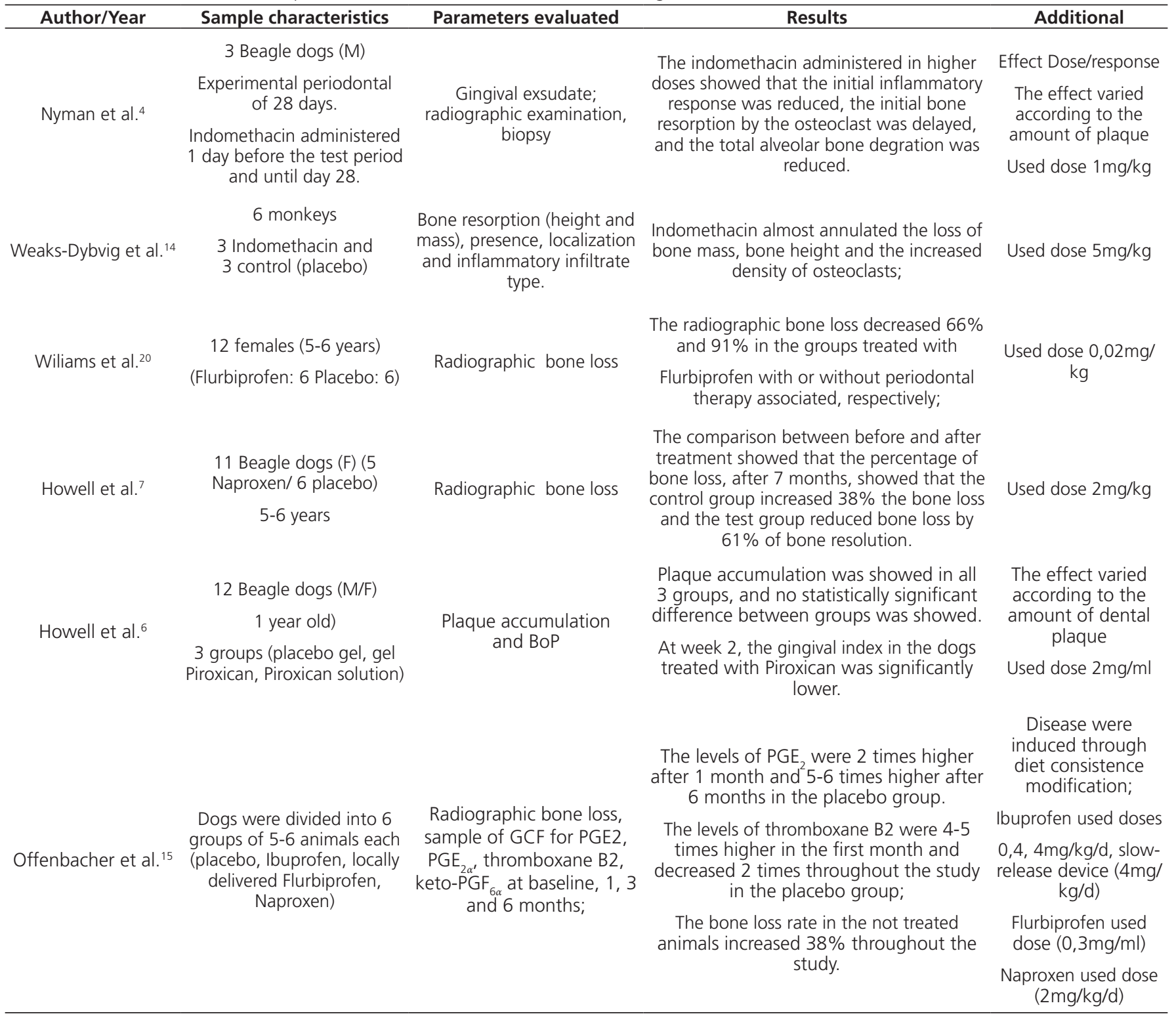

Note: NSAIDs - Nonsteroidal anti-inflammatory drugs, F - Female, M - Male, BoP - bleeding on probing, GCF - gingival crevicular fluid, PGE ${ }_{2}$ Prostaglandin $\mathrm{E}_{2^{\prime}}, \mathrm{PGE}_{2 \alpha}$ - Prostaglandin $\mathrm{E}_{2 \alpha^{\prime}}$ keto- $\mathrm{PGF}_{6 \alpha}-$ Keto-prostaglandin $\mathrm{F}_{6 \alpha}$.

Howell et al. ${ }^{6}$ and Offenbacher et al..$^{15}$ evaluated different NSAIDs and their different administration forms in the gingival bleeding parameters and rate of bone loss. Offenbacher et al. ${ }^{15}$ verified higher arachidonic acid byproducts (ciclooxygenase and thromboxane B2) in the groups not under NSAIDs therapy, indicating a positive correlation between these products and a periodontal homeostasis disruption in Beagle dogs.

Although all the evidences of this review showed beneficial effects of the NSAIDs, the results should be cautiously interpreted since each model presents advantages and disadvantages and a model which could be considered ideal, still does not exist.

\section{Human evidences}

Table 2 demonstrates the 07 studies selected in this literature review regarding the effect of NSAIDs in human periodontal tissues.

Waite et al. ${ }^{16}$ and Feldman et al. ${ }^{17}$ performed two retrospective studies aimed to evaluate the prevalence of periodontal disease in patients using NSAIDs compared to a control group. Age, Plaque Index ${ }^{18}$, Gingival Index ${ }^{19}$, probing 
depth, clinical attachment loss, and radiographic bone loss were evaluated. The results showed that subjects using NSAIDs presented smaller gingival inflammation, probing depth, clinical attachment loss and radiographic alveolar bone loss. However, there was no relation between clinical attachment loss and the duration of the NSAIDs therapy, indicating that a longer usage of these medicines would not represent additional benefits in the periodontal health.

Table 2. Human studies regarding the effect of NSAIDs in the periodontal tissue. Porto Alegre, 2011.

\begin{tabular}{|c|c|c|c|c|}
\hline Author & $\mathbf{n}$ & Parameters evaluated & Results & Observations \\
\hline Waite et al. ${ }^{16}$ & $\begin{array}{l}\text { Case: } 22 \text { patients under NSAIDs } \\
\text { treatment } \\
\text { Control: } 22 \text { individuals with age } \\
\text { and PI similar to the test group }\end{array}$ & $\begin{array}{l}\text { Partial periodontal } \\
\text { examination } \mathrm{PI}, \mathrm{Gl}, \mathrm{PD} \\
\text { and CAL }\end{array}$ & $\begin{array}{l}\text { Cases with smaller gingival inflammation } \\
\text { and PD; } \\
\text { Positive correlation was not } \\
\text { demonstrated between CAL and } \\
\text { duration of therapy with NSAID; } \\
\text { When evaluating only the patients that } \\
\text { used indomethacin ( } n=9 \text { ) there was } \\
\text { statistically significant difference only } \\
\text { for Gl }\end{array}$ & $\begin{array}{c}\text { NSAID for at least } 1 \text { year } \\
\text { The medication seem to } \\
\text { be effective in smaller } \\
\text { plaque levels }\end{array}$ \\
\hline Feldman et al. ${ }^{17}$ & $\begin{array}{l}75 \mathrm{M} \text { therapy with NSAID (test) } \\
75 \mathrm{M} \text { health (control) }\end{array}$ & Radiographic bone loss & $\begin{array}{l}\text { The number of sites showing bone loss } \\
\geq 10 \% \text { was significantly smaller in adults } \\
\text { with rheumatoid arthritis and under } \\
\text { NSAID treatment. }\end{array}$ & $\begin{array}{l}\text { Radiographic bone loss } \\
\text { measured with Schei } \\
\text { ruler }\end{array}$ \\
\hline Williams et al. ${ }^{20}$ & $\begin{array}{l}44 \text { adults ( } 21-70 \text { years) } \\
22 \text { subjects used } 50 \mathrm{mg} \\
\text { Flurbiprofen } 2 x / \text { day } \\
22 \text { subjects used placebo pills }\end{array}$ & $\begin{array}{l}\text { Gl } \\
\text { Radiographic progression } \\
\text { of bone loss; }\end{array}$ & $\begin{array}{l}\text { Gingival inflammation smaller in the test } \\
\text { group. } \\
\text { Lower bone loss from } 6 \text { to } 12 \text { months in } \\
\text { the placebo group and also lower at } 6 \text {, } \\
12 \text { and } 18 \text { months in the test group. } \\
\text { The rates of bone loss returned to initial } \\
\text { values after } 24 \text { months. }\end{array}$ & $\begin{array}{l}\text { Six months periods to } \\
\text { measure the progression } \\
\text { of radiographic bone } \\
\text { loss. }\end{array}$ \\
\hline Heasman \& Seymour ${ }^{21}$ & $\begin{array}{l}50 \text { test }(21 M \text { and } 29 F) \\
42 \text { control (placebo) }(16 M \text { and } \\
26 \mathrm{~F}) \\
\text { Piroxicam }(n=12) \\
\text { lbuprofen }(n=16) \\
\text { Naproxen }(n=12) \\
\text { Indomethacin }(n=10)\end{array}$ & $\begin{array}{l}\text { Partial periodontal } \\
\text { examination PI, GI, PD, } \\
\text { CAL, GR, GCF }\end{array}$ & $\begin{array}{l}\text { No differences between the groups, } \\
\text { except for GCF, that was significantly } \\
\text { lower in the test group; }\end{array}$ & $\begin{array}{l}\text { NSAID use for at least } 2 \\
\text { years ( } 2-30 \text { years) } \\
\text { Individuals with mild } \\
\text { periodontitis }\end{array}$ \\
\hline Jeffcoat et al. ${ }^{9}$ & $\begin{array}{l}15 \text { patients ( } 11 \mathrm{~F} \text { and } 4 \mathrm{M}) \\
\text { (18- } 41 \text { years) } \\
7 \text { test (Naproxen } 500 \mathrm{mg} \\
12 / 12 \text { hours during } 3 \text { months) } \\
8 \text { control (placebo) }\end{array}$ & Radiographic bone loss & $\begin{array}{l}\text { Lower bone loss in the test group; } \\
\text { Radiographic subtraction showed } \\
\text { significant increase in the proportion of } \\
\text { teeth with bone gain in the test group; }\end{array}$ & $\begin{array}{l}\text { Non-surgical treatment } \\
\text { performed by } \\
\text { periodontist. } \\
\text { After } 2 \text { weeks, the } \\
\text { periodontal examination } \\
\text { was conducted at } 5 \\
\text { sites with evidence of } \\
\text { rapid progression of } \\
\text { periodontitis. }\end{array}$ \\
\hline Taiyeb \& Waite ${ }^{8}$ & $\begin{array}{l}17 \text { patients } \\
(12 \mathrm{M} \text { e } 5 \mathrm{~F})\end{array}$ & $\begin{array}{l}\text { Partial periodontal } \\
\text { examination } \\
\text { Color, edema, BoP, PD } \\
\text { and Plaque accumulation }\end{array}$ & $\begin{array}{l}\text { After } 2 \text { weeks, it was shown lower } \\
\text { values for gingival inflammation in both } \\
\text { groups; } \\
\text { lbuprofen improved the clinical status } \\
\text { with and without professional control. }\end{array}$ & $\begin{array}{l}\text { No placebo capsules } \\
\text { delivered to the control } \\
\text { group } \\
\text { Evaluation of } 8 \text { weeks; }\end{array}$ \\
\hline Jeffcoat et al. ${ }^{22}$ & $\begin{array}{l}55 \text { patients } \\
\text { (72\%F e } 28 \% \mathrm{M}) \\
31-64 \text { years, } 18 \text { in the Ketorolac } \\
\text { group (0.1\% mouthwash), } 17 \\
\text { Flurbiprofen } 50 \text { mg systemically, } \\
18 \text { placebo }\end{array}$ & $\begin{array}{l}\text { Radiographic bone loss; } \\
\text { PD; CAL; Pl; Gl; PGE } 2 \text { and } \\
\text { IL1B in the GCF }\end{array}$ & $\begin{array}{l}\text { Smaller bone loss and reduced } \mathrm{PGE}_{2} \text { in } \\
\text { the groups Flurbiprofen and Ketorolac. } \\
\text { Higher bone loss in the placebo group } \\
\text { All groups showed improvements in the } \\
\text { gingival inflammation condition }\end{array}$ & \\
\hline Sekino et al. ${ }^{23}$ & $\begin{array}{l}11 \text { patients } \\
3 \text { group: placebo solution, } 0.1 \% \\
\text { chlorhexidine, and } 200 \mathrm{mg} \\
\text { lbuprofen ( } 2 x / \text { Day) }\end{array}$ & $\mathrm{PI}, \mathrm{Gl}, \mathrm{GCF}$ & $\begin{array}{l}\text { During the placebo rinses, higher biofilm } \\
\text { accumulation and gingivitis signs. } \\
\text { Small amounts of biofilm formed and } \\
\text { the } \mathrm{Gl} \text { scores } \geq 2 \text { during chlorhexidine } \\
\text { rinses. } \\
\text { After } 2 \text { weeks of systemic Ibuprofen } \\
\text { usage, a few sites showed } \mathrm{Gl} \geq 2 \text {, and } \\
\text { the amount of plaque was similar to the } \\
\text { placebo group. }\end{array}$ & $\begin{array}{l}\text { All individuals were } \\
\text { submitted to the } 3 \\
\text { treatment regimens }\end{array}$ \\
\hline
\end{tabular}

Note: NSAIDs - Nonsteroidal anti-inflammatory drugs, PI - Plaque index (Silness \& Löe), GI - Gingival index (Löe \& Silness), PD - Probing depth, CAL - Clinical attachment loss, GR - gingival recession, M - Male, F - Female, GCF - Gingival crevicular fluid, BoP - Bleeding on probing, PGE Prostaglandin $\mathrm{E}_{2}, \mathrm{IL} 1 \mathrm{~B}$ - Interleukin $1 \mathrm{~B}$. 
These results have not considered the type of medication and therapeutic procedure used in each patient, however, when only the patients under indomethacin therapy $(n=9)$ were considered, statistically significant differences were found only for Gingival Index ${ }^{17}$.

Similarly, Heasman \& Seymour ${ }^{20}$ also performed a retrospective study, evaluating the periodontal parameters of patients under NSAIDs treatment of at least 2 years (mean of 9 years) and compared to a control group. It was not found statistically significant differences in the following parameters: Plaque Index ${ }^{18}$, Gingival Index ${ }^{19}$, probing depth, clinical attachment loss, and gingival recession. Statistically significant differences were found only for flow of gingival crevicular fluid, which was higher in the control group.

These cross-sectional studies raise the hypothesis that the use of NSAIDs is related to smaller periodontal inflammation. Several longitudinal studies, with different evaluation periods, were guided in order to assess the effect of NSAIDs in patients with destructive periodontal disease ${ }^{9,}$ 21-22. A summary of these studies is shown in Table 2.

Williams et al. ${ }^{20}$ evaluated the effect of $50 \mathrm{mg}$ Flurbiprofen, twice daily, in the rate of radiographic alveolar bone loss and Gingival Index ${ }^{19}$, during 2.5 years, and compared to a placebo group. It was shown that both groups presented a decrease in the bone loss. On the other hand, the patients under Flurbiprofen therapy showed a smaller gingival inflammation. The rate of bone loss in the placebo group improved significantly 6 and 12 months after therapy when compared to baseline. The Flurbiprofen group showed significantly improvement at 6, 12 and 18 months. At the end of 24 months, there is no difference in the rate of alveolar bone loss between test and placebo groups, indicating that the use of Flurbiprofen, associated with periodontal therapy, has a limited effect on preventing radiographic alveolar bone loss.

Regarding the comparison of different use of NSAIDs (topically and systemically), Jeffcoat et al.22 showed that the groups treated with NSAIDs presented lower bone loss and $\mathrm{PGE}_{2}$ level reductions in the gingival crevicular fluid when compared to the placebo group. Additionally, it is suggested that a mouthwash with Ketorolac preserved more bone tissue when compared to the Flurbiprofen administered systemically. This result indicates that the use of Ketorolac would bring additional benefits in the periodontal disease treatment.

Jeffcoat et al. ${ }^{10}$ evaluated, for 3 months, the efficacy of Naproxen in patients with rapid progression periodontitis. It was shown that, in comparison to the placebo group, the test group showed a significant lower bone loss and an increase in ratio of teeth showing bone gain, evaluated through digital radiographic subtraction method. It is indicated that the Naproxen use, as an adjuvant to periodontal therapy, promotes additional improvement. Some studies, such as those performed by Taiyeb \& Waite ${ }^{8}$ and Sekino et al. ${ }^{23}$, evaluated the gingival margin inflammation in combination with scaling and root planing procedures and the experimental gingivitis model, respectively. The results demonstrate that Ibuprofen promotes additional benefits to the professional control of biofilm and in experimental gingivitis induced by dental plaque. However, the drug did not influence the new dental plaque formation and the inflammation control for longer periods.

Based on these results, it is evident that nonsteroidal anti-inflammatory drugs present a potential to modify the inflammatory response triggered by a bacterial challenge in humans. On the other hand, these results are not predictable at longer periods, and not justified to be used as a therapeutic agent.

However, periodontal literature needs further studies with greater control of variables such as smoking and diabetes in order to explain the actual effect of NSAIDs in the etiopathogenesis of destructive periodontal disease.

\section{Steroidal anti-inflammatory drugs (SAIDS) and periodontal disease}

Animal evidences

The role of SAIDs on the etiopathogenic process of periodontal disease was studied less extensively when compared to the NSAIDs. In this context, only two studies were identified (Table 3). The lack of these studies in the literature limits major generalizations, even within the analysis in rats, the animal model used in both studies.

The study of Kofoed \& Bozzini24, published in 1970, showed that in rats the administration of corticosteroid produce a significant reduction in the concentrations of the amorphous intercellular substance components (chondroitinsulfuric acid and hyaluronic acid), indicating a negative effect on the periodontal homeostasis maintenance, as the tissue loss may occur. However, other mucopolysaccharides analyzed (dermatan sulfate and heparitin sulfate) did not bring differences between the exposed and not exposed groups to corticoid.

Similarly, another study evaluated the effect of dexamethasone on the pathogenesis of the alveolar bone loss in rats. Greater bone loss in the group treated with steroids ${ }^{11}$ was shown. 
Table 3. Animal studies regarding the effect of SAIDs in the periodontal tissues. Porto Alegre, 2011

\begin{tabular}{|c|c|c|c|c|}
\hline Author/Year & $\mathbf{n}$ & $\begin{array}{l}\text { Parameters } \\
\text { evaluated }\end{array}$ & Results & Observations \\
\hline Kofoed \& Bozzini24 & $\begin{array}{l}48 \text { rats ( } 24 \text { test and } 24 \\
\text { control) }\end{array}$ & $\begin{array}{l}\text { Levels of: hyaluronic } \\
\text { acid, heparin sulfate, } \\
\text { chondroitin-4-sulfate, } \\
\text { chondroitin-6-sulfate, } \\
\text { dermatan sulfate and } \\
\text { heparin }\end{array}$ & $\begin{array}{l}\text { Hydrocortisone produced a reduction } \\
\text { in the concentration of hyaluronic } \\
\text { acid, chondroitin-6-sulfate and } \\
\text { heparin. } \\
\text { The remain mucopolysaccharides did } \\
\text { not differ significantly between test } \\
\text { and control groups }\end{array}$ & $\begin{array}{l}\text { Hydrocortisone dose } \\
5 \mathrm{mg} / \mathrm{kg} \text { for } 20 \text { days }\end{array}$ \\
\hline Cavagni et al. ${ }^{11}$ & $\begin{array}{l}26 \text { Wistar rats Wistar (F) } 13 \\
\text { test - Dexametasone and } 13 \\
\text { control-placebo }\end{array}$ & $\begin{array}{l}\text { Morphometric analysis } \\
\text { of alveolar bone loss by } \\
\text { computer program and } \\
\text { digital photographs }\end{array}$ & $\begin{array}{l}\text { Dexamethasone group had greater } \\
\text { bone loss in comparison to the control } \\
\text { group that received a saline solution }\end{array}$ & $\begin{array}{c}\text { Dexametasone dose } \\
0,5 \mathrm{mg} / \mathrm{kg} \\
\text { subcutaneous }\end{array}$ \\
\hline
\end{tabular}

Note: SAIDs - Steroidal anti-inflammatory, F - Female.

Although there is a limitation when translating the results obtained in animal to human studies, both evidences support the concept that the presence of SAIDs, in higher doses, may have a negative role in the periodontal health. The results obtained from the clinical studies in human are responsible for the complementation of this information.

\section{Human evidences}

Similarly to the animal studies, a few studies were found about the role of SAIDs on humans. The three studies considered to be more meaningful for this review are in Table 4, and they were conducted in 1980 and 1990.

Table 4. Human studies regarding the effect of SAIDs in the periodontal tissues Porto Alegre, 2011.

\begin{tabular}{|c|c|c|c|c|}
\hline Author/Year & $\mathbf{N}$ & $\begin{array}{l}\text { Parameters } \\
\text { evaluated }\end{array}$ & Results & Observations \\
\hline Safkan \& Knuutilla ${ }^{12}$ & $\begin{array}{l}\text { Grupo I (27 patients) Grupo } \\
\text { II ( } 26 \text { patients) Grupo III (62 } \\
\text { patients) }\end{array}$ & $\begin{array}{l}\text { VPI, GI, PD, GR, } \\
\text { calculus and alveolar } \\
\text { bone height }\end{array}$ & $\begin{array}{l}\text { VIP, GI: statistically significant } \\
\text { difference between groups I and III; } \\
\text { group I presented more gingivitis } \\
\text { Calculus: group III showed the smallest } \\
\text { percentage } \\
\text { PD and GR: there is no different } \\
\text { among the } 3 \text { groups } \\
\text { Alveolar bone height: there is no } \\
\text { difference between groups I and II. } \\
\text { The group III showed the highest } \\
\text { alveolar bone in comparison to the } \\
\text { other groups }\end{array}$ & $\begin{array}{l}\text { Group I MS under } \\
\text { corticoid effect } \\
\text { Group II MS without } \\
\text { corticoid } \\
\text { Group III Control } \\
\text { Alveolar bone } \\
\text { height measured } \\
\text { in panoramic } \\
\text { radiographs }\end{array}$ \\
\hline Markitziu et al. ${ }^{25}$ & $\begin{array}{l}19 \text { adults patients ( } 7 \text { without } \\
\text { medicines and } 12 \text { under } \\
\text { Prednisone therapy) (mean } \\
\text { dose of } 25.41 \mathrm{mg} \text { ) from } 3 \text { to } \\
13 \text { years }\end{array}$ & $\begin{array}{l}\text { Partial periodontal } \\
\text { examination Salivary } \\
\text { cortisol } \\
\text { PI, MBI, PD, calculus, } \\
\text { GR, alveolar bone } \\
\text { height. }\end{array}$ & $\begin{array}{l}\text { The salivary cortisol levels were } \\
\text { reduced in the patients under } \\
\text { corticoid therapy; } \\
\text { Significantly differences between } \\
\text { groups on MGB and GR; } \\
\text { No alteration in the alveolar bone } \\
\text { height. }\end{array}$ & $\begin{array}{l}\text { Patients examined } \\
\text { twice within } 6 \text { months. }\end{array}$ \\
\hline von Wowern et al. ${ }^{26}$ & $\begin{array}{l}17 \text { patients with acute } \\
\text { nephritis ( } 4 \mathrm{~F} \text { and } 13 \mathrm{M} \text { ) } \\
\text { Comparison with a control } \\
\text { group ( } 50 \mathrm{~F} \text { and } 50 \mathrm{M} \text { ) } \\
\text { ( } 20 \text { to } 42 \text { years) }\end{array}$ & $\begin{array}{l}\text { Jaw and forearm bone } \\
\text { mineral content at the } \\
\text { beginning, } 6 \text { and } 12 \\
\text { months of treatment; } \\
\text { VPI, MBI e CAL ate the } \\
\text { beginning ( } n=17) 6 \\
(n=10) \text { and } 12 \text { months } \\
(n=10)\end{array}$ & $\begin{array}{l}\text { No difference in the loss of bone } \\
\text { mineral content in } 2 \text { sites, among } \\
\text { Prednisone and Deflazacort groups, } \\
\text { on } 2 \text { experimental periods. } \\
\text { No difference in the bone mineral } \\
\text { content between groups, but both } \\
\text { groups lost significantly bone mineral } \\
\text { content. } \\
\text { No significant difference in the } \\
\text { periodontal parameters and mineral } \\
\text { bone loss content of the jaw and } \\
\text { periodontal conditions. }\end{array}$ & $\begin{array}{l}\text { Partial periodontal } \\
\text { examination }\end{array}$ \\
\hline
\end{tabular}

Note: VPI - Visible Plaque Index (Ainamo \& Bay), MBI - Marginal bleeding index (Cowell et al. 1975), GI - Gingival index (Löe \& Silness), PD - Probing depth, CAL - Clinical attachment loss, GR - Gingival recession, MS - Multiple sclerosis, M - Male, F - Female. 
In a cross-sectional study, Safkan \& Knuutilla'2 have shown that subjects using corticosteroid presented more gingivitis. However, the subjects in the control group presented less dental calculus. Additionally, the subjects in the control group showed less alveolar bone loss. Despite all the bias found in this study, there are evidences that subjects who have used corticosteroid, for at least one year, have presented more periodontal disease signs.

On the other hand, Markitziu et al. ${ }^{25}$ evaluated patients with pemphigus vulgaris who were under therapy with corticosteroids. The research showed that the periodontal status of these patients was not statistically significant different regarding the alveolar bone height. Furthermore, a decrease in the levels of salivary cortisol, which is a reduction in the hypothalamic-pituitary-adrenal axis activity, was shown. Regarding the clinical parameters, such as bleeding and gingival recession, statistically significant differences were found between groups. It is important to highlight that, differently from Safkan \& Knutilla ${ }^{12}$, this study evaluated the results before and after the periodontal therapy, which included scaling and root planing and oral hygiene instructions.

Von Wowern et al. ${ }^{26}$ analyzed the alterations in the gingival and bone level of the marginal periodontium related to the mineral bone content of the forearm, measured by scanner, in patients with acute nephritis. The patients were considered skeletally healthy at the beginning of the treatment, and they were divided in two groups according to the medicine used, Prednisone or Deflazacort, which are capable of eliminating smaller calcium quantities in the urine. No significantly differences were found between groups (prednisone and Deflazacort) in the loss of bone mineral content in both forearm and jaw after 6 and 12 months, although, both groups had significant mineral bone loss during the study. Regarding the periodontal parameters (visible plaque index, gingival index, and clinical attachment loss), there were no statistically significant differences between groups.

\section{REFERENCES}

1. Susin C, Rösing CK. Praticando Odontologia baseada em evidências. Canoas: Editora da Ulbra; 1999.

2. Page RC, Kornman KS. The pathogenesis of human periodontitis: an introduction. Periodontol 2000. 1997;14:9-11.
Therefore, based on these results, in patients with longer corticoid usage, osteopenia is a common finding. However, this alteration did not produce effect on periodontal clinical parameters, including alveolar bone height.

The results of these studies related to the effect of SAIDs in the periodontium homeostasis remain controversial. While a few authors found clinical significance to some periodontal clinical parameters ${ }^{12,25}$, others did not show this relation ${ }^{26}$. Further studies are suggested in order to elucidate this relationship.

\section{CONCLUSION}

Through the analyses of the included studies in this review, it is possible to conclude:

The use of NSAIDs, either topically or systemically, may improve the inflammatory parameters in both gingivitis and periodontitis. However, more studies are necessary in order to establish whether these drugs are preventive/ therapeutic agents in the Periodontology.

Evidences in the literature are scarce related to the role of SAIDs in the pathogenesis of gingivitis and periodontitis. However, the studies conducted so far have indicated that these medicines would have deleterious effects on the periodontium. It seems important to study this relationship, once the cortisol - also a glucocorticoid can change the balance in the periodontal health-disease process, mainly as a result of the hypothalamic-pituitaryadrenal axis activation.

\section{Collaborators}

J CAVAGNI was responsible for the study selection, data extraction and the manuscript writing. FWMG MUNIZ helped in the literature review, revised and approved the final version of the manuscript. CK RÖSING was responsible for the study orientation, supervision and selection, data extraction and writing. 
5. Williams RC, Jeffcoat MK, Wechter WJ, Johnson HG, Kaplan ML, Goldhaber P. Non-steroidal anti-inflammatory drug treatment of periodontitis in beagles. J Periodontal Res. 1984;19(6):633-7. doi: 10.1111/j.1600-0765.1984.tb01330.x

6. Howell TH, Fiorellini J, Weber HP, Williams RC. Effect of the NSAID piroxicam, topically administered, on the development of gingivitis in beagle dogs. J Periodontal Res. 1991;26(3 Pt 1):1803. doi: 10.1111/j.1600-0765.1991.tb01643.x

7. Howell TH, Jeffcoat MK, Goldhaber P, Reddy MS, Kaplan ML, Johnson HG, et al. Inhibition of alveolar bone loss in beagles with the NSAID naproxen. J Periodontal Res. 1991;26(6):498-501. doi: 10.1111/j.1600-0765.1991.tb01801.x

8. Taiyeb Ali TB, Waite IM. The effect of systemic ibuprofen on gingival inflammation in humans. J Clin Periodontol. 1993;20(10):723-8. doi: 10.1111/j.1600-051X.1993.tb00697.x

9. Jeffcoat MK, Page R, Reddy M, Wannawisute A, Waite P, Palcanis $K$, et al. Use of digital radiography to demonstrate the potential of naproxen as an adjunct in the treatment of rapidly progressive periodontitis. J Periodontal Res. 1991;26(5):415-21. doi: 10.1111/ j.1600-0765.1991.tb01731.x

10. Jeffcoat MK, Reddy MS. A comparison of probing and radiographic methods for detection of periodontal disease progression. Curr Opin Dent. 1991;1(1):45-51.

11. Cavagni J, Soletti AC, Gaio EJ, Rosing CK. The effect of dexamethasone in the pathogenesis of ligature-induced periodontal disease in Wistar rats. Braz Oral Res. 2005;19(4):2904. doi: 10.1590/S1806-83242005000400010

12. Safkan B, Knuuttila M. Corticosteroid therapy and periodontal disease. J Clin Periodontol. 1984;11(8):515-22. doi: 10.1111/j.1600-051X.1984.tb00903.x

13. Susin C, Rosing CK. O rato como um modelo para o estudo das repercussões do estresse nas doenças. Rev Periodontia. 2002;13:5-10.

14. Weaks-Dybvig M, Sanavi F, Zander H, Rifkin BR. The effect of indomethacin on alveolar bone loss in experimental periodontitis. J Periodontal Res. 1982 Jan;17(1):90-100.

15. Offenbacher $S$, Williams RC, Jeffcoat MK, Howell TH, Odle BM, Smith MA, et al. Effects of NSAIDs on beagle crevicular cyclooxygenase metabolites and periodontal bone loss. J Periodontal Res. 1992 May;27(3):207-13.
16. Waite $\mathbf{M}$, Saxton $C A$, Young $A$, Wagg BJ, Corbett $M$. The periodontal status of subjects receiving non-steroidal antiinflammatory drugs. J Periodontal Res. 1981 Jan;16(1):100-8.

17. Feldman RS, Szeto B, Chauncey HH, Goldhaber P. Non-steroidal anti-inflammatory drugs in the reduction of human alveolar bone loss. J Clin Periodontol. 1983 Mar;10(2):131-6.

18. Silness J, Loe H. Periodontal Disease in Pregnancy. li. Correlation between Oral Hygiene and Periodontal Condtion. Acta Odontol Scand. 1964 Feb;22:121-35.

19. Loe H, Silness J. Periodontal Disease in Pregnancy. I. Prevalence and Severity. Acta Odontol Scand. 1963 Dec;21:533-51.

20. Williams RC, Jeffcoat MK, Howell TH, Rolla A, Stubbs D, Teoh $\mathrm{KW}$, et al. Altering the progression of human alveolar bone loss with the non-steroidal anti-inflammatory drug flurbiprofen. J Periodontol. 1989 Sep;60(9):485-90.

21. Heasman PA, Seymour RA. An association between long-term non-steroidal anti-inflammatory drug therapy and the severity of periodontal disease. J Clin Periodontol. 1990 Oct;17(9):654-8.

22. Jeffcoat MK, Reddy MS, Haigh S, Buchanan W, Doyle MJ, Meredith MP, et al. A comparison of topical ketorolac, systemic flurbiprofen, and placebo for the inhibition of bone loss in adult periodontitis. J Periodontol. 1995 May;66(5):329-38.

23. Sekino $S$, Ramberg $P$, Lindhe J. The effect of systemic administration of ibuprofen in the experimental gingivitis model. J Clin Periodontol. 2005 Feb;32(2):182-7.

24. Kofoed JA, Bozzini CE. The effect of hydrocortisone on the concentration and synthesis of acid mucopolysaccharides in the rat gingiva. J Periodontal Res. 1970;5(4):259-62.

25. Markitziu A, Zafiropoulos G, Flores de Jacoby L, Pisanty S. Periodontal alterations in patients with pemphigus vulgaris taking steroids. A biannual assessment. J Clin Periodontol. 1990 Apr;17(4):228-32.

26. von Wowern N, Klausen B, Olgaard K. Steroid-induced mandibular bone loss in relation to marginal periodontal changes. J Clin Periodontol. 1992 Mar;19(3):182-6.

Received on: 25/2/2016 Final version resubmitted on: 17/3/2016 Approved on: 15/5/2016 